\title{
ANALISIS PENGARUH RETURN ON ASSET (ROA), BIAYA OPERASIONAL TERHADAP PENDAPATAN OPERASIONAL (BOPO), SUKU BUNGA, FINANCING TO DEPOSITS RATIO (FDR) DAN NON PERFORMING FINANCING (NPF) TERHADAP TINGKAT BAGI HASIL DEPOSITO MUDHARABAH
}

(Studi Empiris pada Bank Umum Syariah di Indonesia Tahun 2011-2013)

\author{
Nana Nofianti, Tenny Badina, Aditiya Erlangga
}

Universitas Sultan Ageng Tirtayasa

\begin{abstract}
Level of profit sharing given by Islamic Banks which is one factor public appeal to save funds in the products of Islamic Banks but in level of profit sharing for giving of Islamic Banks still refers to the rate of Conventional Banks. Still referring to Conventional Bank interest rates make people still think that the same Islamic Banks with Conventional Banks. This research purpose to analyze the effect of financial ratios and interest rate to the level of profit sharing of mudharabah deposits Islamic Banks in Indonesia. The population used is the quarterly financial statements throughout Islamic Banks in Indonesia 2011-2013. Selection of the samples tested in this study using purposive sampling method, 6 selected Islamic Banks. Analysis tools in this study is used multiple regression analysis using SPSS 19.0 software. The variables used in this study are Return On Asset (ROA), BOPO, Interest Rate, Financing To Deposits Ratio (FDR) and Non Performing Financing (NPF) as the independent variable, and level of profit sharing mudaraba deposits as the dependent variable. Partial results show that Return On Asset (ROA) and Financing To Deposits Ratio (FDR) significant positive effect on level of profit sharing mudaraba deposits while the BOPO, Interest Rate and Non Performing Financing (NPF) have no effect.
\end{abstract}

Keywords : Return On Asset (ROA), BOPO, Interest Rate, Financing To Deposits Ratio (FDR) , Non Performing Financing (NPF), Level of profit sharing mudaraba deposits, Islamic Banks

Abstrak. Tingkat bagi hasil yang diberikan oleh bank syariah merupakan salah satu daya tarik publik untuk menyimpan dana dalam produk bank syariah, tetapi di tingkat bagi hasil, bank syariah juga masih mengacu pada bank konvensional. Karna masih mengacu pada suku bunga bank konvensional membuat orang masih berpikir bahwa bank syariah sama dengan bank konvensional. Penelitian ini bertujuan untuk menganalisis pengaruh rasio keuangan dan tingkat bunga dengan tingkat bagi hasil deposito mudharabah bank syariah di Indonesia. Populasi yang digunakan adalah laporan keuangan triwulanan seluruh bank syariah di Indonesia 2011-2013. Pemilihan sampel yang diuji dalam penelitian ini menggunakan metode purposive sampling, 6 bank syariah yang dipilih. Pada penelitian ini digunakan analisis regresi berganda dengan menggunakan perangkat lunak SPSS 19,0. Variabel yang digunakan dalam penelitian ini adalah Return On Asset (ROA), BOPO, Suku Bunga, Financing to Deposit Ratio (FDR) dan Non Performing Financing (NPF) sebagai variabel independen, dan tingkat bagi hasil deposito mudharabah berbagi sebagai variabel dependen. Sebagian hasil menunjukkan bahwa Return On Asset (ROA) dan Financing to Deposit Ratio (FDR) 
berpengaruh positif secara signifikan terhadap tingkat bagi hasil deposito mudharabah sedangkan BOPO, Suku Bunga dan Non Performing Financing (NPF) tidak berpengaruh. Keywords: Return On Asset (ROA), BOPO, Suku Bunga, Financing To Deposits Ratio (FDR) , Non Performing Financing (NPF), tingkat bagi hasil deposito mudharabah, Bank Syariah.

\section{Pendahuluan}

Bank merupakan suatu lembaga yang berperan sebagai perantara keuangan (financial intermediary) antara pihak-pihak yang memiliki dana (surplus unit) dengan pihak-pihak yang membutuhkan dana (deficit unit) \& bank itu sendiri dianggap sebagai lembaga yang berfungsi memperlancar aliran lalu lintas pembayaran. Sebagai industri yang dalam kegiatan usahanya mengandalkan kepercayaan masyarakat, memelihara tingkat kesehatan dan kinerja bank menjadi penting untuk dilakukan (Merkusiwati, 2007).

Eksistensi bank syariah sendiri di Indonesia secara formal telah dimulai sejak tahun 1992 dengan diberlakukannya UU No.7 tahun 1992 tentang perbankan sebagaimana telah diubah dengan Undang-Undang No. 10 tahun 1998. Dalam Undang-Undang tersebut tertulis bahwa bank umum melaksanakan kegiatan usaha secara konvensional dan atau berdasarkan prinsip syariah (bank syariah) yang dalam kegiatannya memberikan jasa dalam lalu lintas pembayaran. Undang-Undang tersebut memberi kebebasan kepada bank dalam menentukan jenis imbalan yang akan diberikan kepada nasabah, baik berupa bunga ataupun keuntungan bagi hasil, termasuk keleluasaan penentuan tingkat bunga sampai 0 (nol) dan merupakan hal baru dalam kerangka mekanisme sistem perbankan pada umumnya (Khasanah, 2012).

Mekanisme kerja bank syariah pada dasarnya sama dengan bank konvensional, yaitu menghimpun dana dari masyarakat dan menyalurkannya kembali ke masyarakat dalam bentuk kredit atau pembiayaan. Perbedaan antara bank syariah dengan bank konvensional adalah adanya larangan bunga dalam bank syariah sebagaimana sistem bunga yang dianut oleh bank konvensional. Berdasarkan hal ini, maka pendapatan dari penyimpanan dana tidak didasarkan dalam bentuk persentase yang ditetapkan (bunga) tetapi ditentukan dalam bentuk rasio bagi hasil terhadap pendapatan yang diperoleh. Dengan demikian, konsekuensi dari sistem ini 
adalah uang yang didapatkan hasil dari pengelolaan dana tetap tergantung pada pendapatan yang diterima (Sri, et al, 2013).

Per Oktober 2013, tercatat sudah 11 Bank Umum Syariah (BUS), 23 Unit Usaha Syariah (UUS), 160 Bank Pembiayaan Rakyat Syariah (BPRS) dengan jumlah kantor perbankan syariah sebanyak 2925 yang tersebar di hampir seluruh wilayah Indonesia. Meningkatnya jumlah Bank dan kantor perbankan syariah yang beroperasi di Indonesia ini memberikan dampak positif bagi perkembangan industri perbankan syariah. Peningkatan ini memberikan kemudahan bagi masyarakat Indonesia untuk dapat menikmati layanan dari perbankan syariah. Menurut Anisah dkk., (2013) Perkembangan yang pesat pada Bank Syariah di Indonesia ini dianggap karena selama ini Bank Syariah mampu membidik pasar syariah loyalis, yaitu konsumen yang meyakini bahwa bunga Bank itu haram. Di lain pihak, Bank Syariah sedang mengalami kondisi persaingan yang sangat ketat karena semua pihak yang terlibat dalam perbankan sama-sama bergerak di pasar rasional yang sensitif terhadap bunga. Para depositor sendiri sangat memperhatikan return atau keuntungan yang mereka peroleh ketika menginvestasikan uangnya di Bank.

Penelitian yang dilakukan oleh Erol dan El-Bdour (1998) yang dikutip dalam Muhammad (2004) menunjukkan bahwa masyarakat sebetulnya lebih berorientasi pada profit daripada agama. Mawardi (2008) juga menegaskan faktor yang menjadi pertimbangan masyarakat menginvestasikan dananya di Bank Syariah adalah faktor return bagi hasil.

Penelitian yang dilakukan oleh Husnelly (2003) dan Mangkuto (2004) yang dikutip dalam Mawardi (2008) Bank Syariah harus tetap menjaga kualitas tingkat bagi hasil yang diberikan nasabahnya. Nasabah penyimpan dana akan selalu mempertimbangkan tingkat imbalan yang diperoleh dalam melakukan investasi pada Bank Syariah. Jika tingkat bagi hasil Bank Syariah terlalu rendah maka tingkat kepuasan nasabah akan menurun dan kemungkinan besar akan memindahkan dananya ke Bank lain. Karakteristik nasabah yang demikian membuat tingkat bagi hasil menjadi faktor penentu kesuksesan Bank Syariah dalam menghimpun Dana Pihak Ketiga. 
Berdasarkan Tabel 1 di bawah ini kita dapat mengetahui perkembangan pengumpulan Dana Pihak Ketiga perbankan syariah secara keseluruhan yang ada di Indonesia.

Tabel 1 Perkembangan Dana Pihak Ketiga BUS dan UUS (Rp Triliun)

\begin{tabular}{|l|r|r|r|r|r|r|}
\hline \multirow{2}{*}{ Dana Pihak Ketiga } & \multicolumn{2}{|c|}{ Okt-10 } & \multicolumn{2}{c|}{ Okt-11 } & \multicolumn{2}{c|}{ Growth } \\
\cline { 2 - 8 } & Nominal & $\begin{array}{c}\text { Share } \\
(\%)\end{array}$ & Nominal & $\begin{array}{c}\text { Share } \\
(\%)\end{array}$ & Nominal & \multicolumn{1}{c|}{$(\%)$} \\
\hline $\begin{array}{l}\text { Total Dana Pihak } \\
\text { Ketiga }\end{array}$ & 66,48 & 100,00 & 101,57 & 100,00 & 35,10 & 52,79 \\
\hline Tabungan & 19,33 & 29,07 & 27,81 & 27,38 & 8,49 & 43,93 \\
\hline$\bullet \quad$ Wadiah & 2,18 & & 4,33 & & 2,15 & 98,53 \\
\hline$\bullet \quad$ Mudharabah & 17,15 & & 23,49 & & 6,34 & 36,99 \\
\hline Deposito & 39,23 & 59,01 & 62,02 & 61,06 & 22,79 & 58,11 \\
\hline Giro (Wadiah) & 7,12 & 10,70 & 11,05 & 10,88 & 3,94 & 55,31 \\
\hline Lainnya & 0,81 & 1,22 & 0,69 & 0,68 & $-0,12$ & $-15,04$ \\
\hline
\end{tabular}

Sumber : Outlook Perbankan syariah 2012

Data diatas menunjukan Penghimpunan dana perbankan syariah mengalami peningkatan yang tinggi selama satu tahun terakhir dari Rp 66,48 triliun pada Oktober 2010 menjadi Rp 101,57 triliun pada Oktober 2011 atau meningkat 52,79\%. Sementara untuk Penghimpunan dana masyarakat sebagaimana dalam Tabel 1.2, terbesar adalah dalam bentuk deposito yaitu Rp 62,02 triliun (61,06\%) diikuti oleh Tabungan sebesar Rp27,81 triliun (27,38\%) dan Giro sebesar Rp11,05 triliun $(10,88 \%)$.

Berdasarkan perkembangan pada setiap jenis produknya, produk deposito merupakan produk yang stabil mengalami peningkatan sepanjang tahun 2011. Deposito merupakan produk yang tingkat pertumbuhannya sangat tinggi yaitu sekitar 61,06\% dari posisi tahun lalu Rp 39,23 triliun menjadi Rp 62,02 triliun. Dari sisi preferensi masyarakat terhadap produk-produk perbankan syariah, masyarakat masih cenderung memilih produk yang memberikan imbal hasil yang tinggi. Imbal hasil deposito berfluktuasi antara 7,24\% sampai dengan 9,11\% (equivalent rate), sedangkan imbal hasil tabungan sekitar 2,91\% dan giro sekitar 1,47\% (equivalent rate). Dengan demikian wajarlah apabila produk simpanan berjangka (deposito) lebih diminati dibandingkan produk tabungan. Lebih lanjut, produk deposito yang paling diminati masyarakat adalah deposito 1 (satu) bulan (Outlook Perbankan syariah Indonesia 2012). 
Fatwa DSN Nomor 3 Tahun 2000 menyatakan bahwa deposito yang dibenarkan dalam syariah adalah deposito yang berdasarkan prinsip mudharabah. Dalam transaksi deposito mudharabah, nasabah bertindak sebagai pemilik dana (shahibul maal) sedangkan Bank bertindak sebagai pengelola dana (mudharib) dalam kapasitasnya sebagai mudharib, Bank Syariah dapat melakukan berbagai macam usaha yang tidak bertentangan dengan prinsip syariah serta mengembangkannya, termasuk melakukan akad mudharabah pada dana dari pihak ketiga (Rizqiana, 2010).

Tidak seperti Bank konvensional yang menawarkan deposito dengan konsep bunga, Bank Syariah hadir dengan menawarkan deposito mudharabah konsep bagi hasil. Bagi Hasil (profit sharing) antara Bank dengan nasabah dalam pengelolaan dananya digunakan sebagai prinsip dalam perbankan syariah. Profit sharing menekankan bahwa simpanan yang ditabung pada Bank Syariah nantinya akan digunakan untuk pembiayaan oleh Bank Syariah, kemudian hasil atau keuntungan yang didapat akan dibagi menurut nisbah yang disepakati bersama. Tingkat bagi hasil yang tinggi akan menarik nasabah dalam memilih perbankan (Nelwani, 2013).

Menurut Mawardi (2008) dalam Aisiyah (2010) saat ini terjadi kritik pada salah satu skim perbankan syariah, yaitu pada skim deposito mudharabah mutlaqah, yang merupakan salah satu produk penyaluran dana Bank Syariah. Kritik itu diberikan karena adanya indikasi bahwa dalam return bagi hasil deposito mudharabah Bank- Bank Syariah mengacu pada tingkat suku bunga Bank konvensional.

Indikasi rate of return sebagai presentase tingkat bagi hasil simpanan Bank Syariah dipengaruhi oleh banyak faktor, baik faktor internal maupun faktor eksternal. Faktor internal terutama terkait dengan kinerja manajemen Bank Syariah itu sendiri seperti efektivitas fungsi intermediasi, efisiensi operasional, dan kemampuan profitabilitas. Disamping itu, kondisi makro ekonomi sebagai faktor eksternal yang tidak bisa dikendalikan oleh manajemen juga cukup berpengaruh terhadap hasil yang diterima dari hasil pembiayaan yang disalurkan (Khairiah dan Kunti, 2012).

Beberapa penelitian mengenai faktor-faktor yang mempengaruhi tingkat bagi hasil deposito mudharabah telah banyak dilakukan diantaranya adalah Anggrainy (2010) menggunakan rasio profitabilitas (ROA \& ROE), rasio efisiensi (BOPO), rasio likuiditas (FDR) dan rasio solvabilitas (CAR) sebagai faktor internal yang dianggap 
mempengaruhi tingkat bagi hasil deposito mudharabah. Hasil penelitiannya menunjukan bahwa ROA \& BOPO berpengaruh positif signifikan terhadap tingkat bagi hasil deposito mudharabah, sedangkan ROE, FDR \& CAR tidak berpengaruh terhadap tingkat bagi hasil deposito mudharabah. Sementara Khairiah dan Kunti (2012) menggunakan dua rasio keuangan sebagai faktor internal dan satu faktor eksternal yaitu suku bunga yang dianggap mempunyai pengaruh terhadap tingkat bagi hasil deposito mudharabah. Hasilnya menunjukan faktor yang mempengaruhi tingkat bagi hasil deposito mudharabah adalah ROA, BOPO dan suku bunga. Hasil penelitian Khairiah dan Kunti (2012) menunjukan bahwa ROA \& Suku Bunga mempunyai pengaruh positif terhadap tingkat bagi hasil deposito mudharabah sedangkan BOPO tidak mempunyai pengaruh terdapat tingkat bagi hasil deposito mudharabah.

Return On Asset (ROA) merupakan salah satu rasio profitabilitas yang digunakan untuk mengukur efektifitas perusahaan di dalam menghasilkan keuntungan dengan memanfaatkan total aset yang dimilikinya. Return On Asset (ROA) merupakan rasio antara laba sebelum pajak terhadap rata-rata total aset Bank. Semakin besar nilai ROA, maka semakin besar pula kinerja perusahaan, karena return yang diperoleh perusahaan semakin besar Khiriah dan Kunti (2012). Penelitian mengenai return on asset (ROA) menunjukan hasil yang berbeda, Pramilu (2012) menunjukan hasil bahwa return on asset (ROA) berpengaruh negatif terhadap tingkat bagi hasil deposito mudharabah, sedangkan penelitian Juwairiyah (2008) dan Anggrainy (2010) menunjukan bahwa return on asset (ROA) berpengaruh positif signifikan terhadap tingkat bagi hasil deposito mudharabah.

Rasio efisiensi diwakili dengan Biaya Operasional per Pendapatan Operasional (BOPO) yaitu rasio yang digunakan untuk mengukur perbandingan biaya operasi atau biaya intermediasi terhadap pendapatan operasi yang diperoleh Bank. Semakin kecil angka rasionya, maka semakin baik kondisi Bank tersebut (Anggrainy, 2010). Hasil penelitian Pramilu (2012) menunjukan bahwa Biaya Operasional terhadap Pendapatan Operasional (BOPO) berpengaruh negatif terhadap tingkat bagi hasil deposito mudharabah, sedangkan penelitian Anggrainy (2010) dan Juwairiyah (2008) menunjukan bahwa Biaya Operasional terhadap Pendapatan Operasional (BOPO) berpengaruh positif signifikan terhadap tingkat bagi hasil deposito mudharabah. 
Tingkat suku bunga merupakan salah satu faktor ekonomi makro yang mempengaruhi jumlah deposito mudharabah pada Bank Syariah. Rasio tersebut merupakan faktor penentu yang menjadi ketertarikan masyarakat dalam mendepositokan dananya di Bank Syariah karena dianggap mereka akan memperoleh keuntungan yang lebih besar.

Dengan adanya suku bunga yang lebih tinggi, masyarakat lebih terdorong untuk mengorbankan/mengurangi pengeluaran mereka untuk konsumsi, dan memilih untuk menyimpan uang mereka di Bank (Nelwani, 2013). Penelitian mengenai tingkat suku bunga yang dilakukan Azmy (2008), Khairiah dan Kunti (2012) menunjukan hasil yang saling mendukung yaitu tingkat suku bunga berpengaruh positif signifikan terhadap tingkat bagi hasil deposito mudharabah.

Financing to Deposits Ratio (FDR) merupakan rasio pembiayaan terhadap dana pihak ketiga yang menggambarkan sejauh mana simpanan digunakan untuk pemberian pembiayaan yang biasa digunakan untuk mengukur tingkat likuiditas perbankan syariah dengan membandingkan jumlah kredit yang disalurkan dengan jumlah deposit yang dimiliki. Semakin tinggi rasio ini, maka tingkat likuiditas Bank semakin rendah, karena jumlah dana yang digunakan untuk membiayai kredit semakin kecil, demikian pula sebaliknya (Amelia, 2011). Penelitian mengenai Financing to Deposits Ratio (FDR) menunjukan hasil yang berbeda, Arifa (2008) menunjukan hasil bahwa Financing to Deposits Ratio (FDR) tidak berpengaruh terhadap tingkat bagi hasil deposito mudharabah, sedangkan penelitian Amelia (2011) menunjukan bahwa Financing to Deposits Ratio (FDR) berpengaruh positif signifikan terhadap tingkat bagi hasil deposito mudharabah.

Non Performing Financing (NPF) adalah rasio antara jumlah pembiayaan yang tidak tertagih atau tergolong non lancar dengan kualitas kurang lancar, diragukan dan macet (Arifa, 2008). Jika Non Performing Financing (NPF) tinggi, maka profitabilitas menurun dan tingkat bagi hasil menurun dan jika Non Performing Financing (NPF) turun, maka profitabilitas naik dan tingkat bagi hasil naik. Adapun standar terbaik Non Performing Financing (NPF) adalah kurang dari 5\%.

Penelitian mengenai Non Performing Financing (NPF) yang dilakukan Arifa (2008) dan Amelia (2011) menunjukan hasil yang saling mendukung yaitu Non 
Performing Financing (NPF) berpengaruh positif signifikan terhadap tingkat bagi hasil deposito mudharabah.

Penelitian ini meneliti faktor-faktor yang mempengaruhi tingkat bagi hasil Deposito Mudharabah pada Bank Umum Syariah di indonesia. Penelitian ini merupakan pengembangan dari penelitian Khairiah dan Kunti (2012) yang menggunakan variabel Return On Asset (ROA), Biaya Operasional terhadap Pendapatan Operasional (BOPO), Suku Bunga dan menambah dua variabel yaitu Financing to Deposits Ratio (FDR) dan Non Performing Financing (NPF). Variabel Financing to Deposits Ratio (FDR) diambil dari Arifa (2008). Alasan menambah variabel Financing to Deposits Ratio (FDR) dikarenakan dalam penetapan return bagi hasil yang diterima nasabah deposan tersebut mengacu pada tingkat suku bunga konvensional. Padahal tingginya tingkat bagi hasil yang ditawarkan perbankan syariah tidak terlepas dari besarnya tingkat pembiayaannya dan kualitas aset Bank yang dapat dilihat dari tingkat Financing to Deposits Ratio (FDR) dan Non Performing Financing (NPF) perbankan syariah. Sebagai produk tabungan berjangka, pada umumnya nisbah bagi hasil deposito akan lebih besar dari produk tabungan biasa. Bagi hasil dapat dilakukan secara tunai, atau secara otomatis dikreditkan ke rekening tabungan atau giro, atau ditambahkan ke pokok deposito. Menurut Aisiyah (2010) semakin tinggi rasio Financing to Deposits Ratio (FDR) mengindikasikan tingkat pembiayaan yang tinggi dan ini berdampak pada meningkatnya return yang akan dihasilkan dari pembiayaan. Hal tersebut secara otomatis akan meningkatkan tingkat bagi hasil.

Perbedaan dengan penelitian sebelumnya adalah penambahan 2 variabel independen yaitu variabel financing to deposits ratio (FDR) dan non performing financing (NPF) sekaligus menambah jumlah sampel yang digunakan. Pada penelitian Khairiah dan Kunti (2012) variabel independen yang digunakan adalah 3 variabel independen yaitu Return On Asset (ROA), Biaya Operasional terhadap Pendapatan Operasional (BOPO), dan Suku Bunga, sedangkan sampel yang digunakan hanya 3 Bank Umum Syariah yang tercatat pada Statistik Perbankan Indonesia periode 20092011, sedangkan sampel pada penelitian ini menggunakan 6 Bank Umum Syariah yang tercatat pada Bank Indonesia tahun 2011 - 2013. Alasan menggunakan sampel 6 Bank Umum Syariah adalah merujuk pada penelitian Khairiah dan Kunti (2012) dan 
Hermawan (2013) yaitu hanya Bank Syariah Mandiri, Bank BRI Syariah, Bank Mega Syariah, Bank Panin Syariah, Bank Central Asia Syariah, dan Bank Negara Indonesia Syariah yang menerbitkan laporan keuangan triwulan secara lengkap (Neraca, Laporan Laba Rugi, dan Distribusi Bagi Hasil) pada tahun 2011-2013. Oleh karena itu penulis mencoba menambahkan jumlah sampel dalam penelitian ini karena dianggap memiliki kelengkapan data yang dibutuhkan dalam penelitian ini.

Berdasarkan latar belakang diatas maka penulis tertarik untuk melakukan penelitian mengenai tingkat bagi hasil deposito mudharabah pada Bank Umum Syariah yang ada di Indonesia, sehingga penulis mengangkat judul " Analisis Pengaruh Return On Asset (ROA), Biaya Operasional terhadap Pendapatan Operasional (BOPO) , Suku Bunga, Financing to Deposits Ratio (FDR) dan Non Performing Financing (NPF) terhadap Tingkat bagi hasil Deposito Mudharabah (Studi Empiris Pada Bank Umum Syariah di Indonesia)" .

\section{Metode Penelitian}

\subsection{Sumber data, Populasi dan Sampel}

Data yang digunakan dalam penelitian ini diperoleh dari data sekunder. Data sekunder biasanya telah dikumpulkan oleh lembaga pengumpul data dan dipublikasikan kepada masyarakat pengguna data (Sugiyono, 2010). Sumber data dalam penelitian ini yaitu Bank Syariah di Indonesia yang tercatat sebagai Bank Umum Syariah yang diunduh dari situs resmi Bank perusahaan sampel.

Populasi dalam penelitian ini adalah seluruh Bank Umum Syariah di Indonesia pada tahun 2011-2013. Sampel dipilih berdasarkan (purposive sampling), yaitu memilih sampel yang memenuhi kriteria-kriteria tertentu. Bank Umum Syariah yang diambil sebagai sampel adalah Bank Umum Syariah yang tercatat pada Bank Indonesia pada periode 2011-2013 dan Bank Umum Syariah yang menyajikan laporan keuangan triwulanan secara lengkap (Neraca, laporan laba Rugi, dan Distribusi Bagi hasil) pada periode 2011-2013 yang dapat diakses melalui internet. Lampiran 2 menyajikan daftar nama perusahaan yang dijadikan sampel. 


\subsection{Metode Analisis Data}

Uji hipotesis dilakukan dengan cara uji signifikansi (pengaruh nyata) variabel independen $(\mathrm{X})$ terhadap variabel dependen $(\mathrm{Y})$. Dalam penelitian ini digunakan analisis regresi linear berganda. Analisis regresi digunakan oleh peneliti apabila bermaksud meramalkan bagaimana keadaan (naik-turunnya) variabel dependen, dan apabila dua atau lebih variabel independen sebagai prediktor dimanipulasi atau dinaik turunkan nilainya. Untuk pengujian hipotesis yaitu dengan menggunakan analisis regresi berganda, berikut model regresi tersebut:

$$
\mathrm{Y}_{\text {it }}=\boldsymbol{\alpha}+\boldsymbol{\beta}_{\mathbf{1}} \mathrm{ROA}_{\mathrm{it}}+\boldsymbol{\beta}_{\mathbf{2}} \mathrm{BOPO}_{\mathrm{it}}+\boldsymbol{\beta}_{3} \mathrm{Suku} \text { Bunga }_{i t}+\boldsymbol{\beta}_{\mathbf{4}} \mathrm{FDR}_{\mathrm{it}}+\boldsymbol{\beta}_{5} \mathrm{NPF}_{\mathrm{it}}+\mathrm{e}_{\mathrm{it}}
$$

Keterangan Persamaan Regresi Berganda:

\begin{tabular}{|ll|}
\hline Simbol & Keterangan \\
Yi & Tingkat Bagi Hasil (Variabel Dependen) \\
$\alpha$ & Konstanta persamaan regresi \\
$\beta_{1-5}$ & Koefisien variabel independen \\
ROA & Return On Asset \\
BOPO & Biaya Operasional terhadap Pendapatan Operasional \\
Suku & \\
Bunga & Suku Bunga \\
FDR & Financing to Deposits Ratio \\
NPF & Non Performing financing \\
\hline
\end{tabular}

\section{PEMBAHASAN}

\subsection{Hasil Analisis Statistik Deskriptif}

Variabel Tingkat Bagi Hasil (TBH) menunjukkan rata-rata sebesar 5,9201 dengan standar deviasi sebesar 0,97225. Nilai minimum menunjukkan sebesar 4,03 nilai maksimum menunjukkan sebesar 8,27. Variabel Non Performing Financing (NPF) menunjukkan rata-rata sebesar 1,1942. Nilai NPF minimum diperoleh sebesar 0,00 dan nilai maksimum NPF terbesar adalah sebesar 3,26 dengan standart deviasi sebesar 0,88666. Variabel Financing to Deposits Ratio (FDR) menunjukkan rata-rata sebesar 95,8335. Nilai FDR minimum diperoleh sebesar 74,14 dan FDR terbesar adalah sebesar 205,31 dengan standart deviasi sebesar 21,19224. Variabel Suku Bunga menunjukkan rata-rata sebesar 6,3975. Nilai Suku Bunga minimum diperoleh sebesar 5,64 
dan Suku Bunga terbesar adalah sebesar 7,61 dengan standart deviasi sebesar 0,65095 . Variabel Biaya Operasional terhadap pendapatan Operasional (BOPO) menunjukkan rata-rata sebesar 83,8869. Nilai BOPO minimum diperoleh sebesar 50,76 dan BOPO terbesar adalah sebesar 134,10 dengan standart deviasi sebesar 12,88750. Variabel Return On Asset (ROA) menunjukkan rata-rata sebesar 1,6383. Nilai ROA minimum diperoleh sebesar $-1,55$ dan ROA terbesar adalah 4,13 dengan standart deviasi sebesar 1,07304.

\subsection{Analisis Hasil dan Pembahasan}

Hasil pengujian tolerance menunjukkan tidak ada variabel bebas yang memiliki nilai tolerance kurang dari 0,1. Hasil perhitungan VIF juga menunjukkan bahwa tidak ada satu variabel bebas yang memiliki nilai VIF lebih dari 10. Oleh karena itu, dapat disimpulkan bahwa tidak ada multikolinearitas antara variabel dalam model regresi tersebut. Hasil uji autokolerasi menunjukkan bahwa nilai DW pada model regresi sebesar 1,032, , nilai ini akan dibandingkan dengan tabel DW yang menggunakan signifikansi $5 \%$, jumlah sampel $72(\mathrm{n}=72)$ dan jumlah variabel independen $5(\mathrm{k}=5)$. Berdasarkan tabel DW tersebut didapatkan nilai dl (batas luar) sebesar 1,464 dan du (batas dalam) sebesar 1,768. Oleh karena nilai DW sebesar 1,032 lebih kecil dari batas luar (du) 1,032 <1,464 dan lebih besar dari nol yaitu 1,032 >0 maka dapat disimpulkan bahwa tidak ada autokorelasi positif atau tolak $\mathrm{H}_{0}$.

Selain itu untuk mendeteksi terjadi atau tidaknya autokorelasi adalah dengan menggunakan uji Run Test. Uji Run Test merupakan sebagai bagian dari statistic non-parametrik dapat pula digunakan untuk menguji apakah antar residual terdapat korelasi yang tinggi. Jika antar residual tidak terdapat hubungan korelasi maka dikatakan bahwa residual adalah acak atau random. Run Test digunakan untuk melihat apakah data residual terjadi secara random atau tidak (sistematis).

H0 : residual (res_1) random (acak)

HA : residual (res_1) tidak random

Hasil dari uji Run Test menunjukkan bahwa nilai test adalah -2,31 dengan probabilitas 0,590 tidak signifikan pada 0,05 yang berarti hipotesis nol 
diterima, sehingga dapat disimpulkan bahwa residual random atau tidak terjadi autokorelasi antar nilai residual.

Hasil uji Goodness of Fit Model menunjukkan bahwa model dinyatakan Fit sebagaimana dapat dilihat dari uji determinasi menunjukkan nilai Adjusted $R$ Square sebesar 0.466, selain itu hasil pengolahan data terlihat bahwa nilai $\mathrm{F}$ $=11,278$ dengan signifikan sebesar 0,000 $<0,05$. Nilai signifikan pengujian yang lebih kecil dari $\alpha=0,05$ menunjukkan bahwa model regresi dapat dikatakan baik, sehingga dapat dilanjutkan ke pengujian atau dapat disimpulkan model regresi secara simultan berpengaruh secara signifikan.

\subsection{Pengaruh Return On Asset (ROA) terhadap Tingkat Bagi Hasil Deposito Mudharabah}

Berdasarkan hasil pengujian variabel Return On Asset (ROA) terhadap tingkat bagi hasil deposito mudharabah (TBH) diperoleh hasil bahwa nilai $\beta 1$ sebesar 0,127 dengan tingkat signifikan sebesar 0,000 berada lebih kecil pada $\alpha=0,05$, Hasil tersebut menunjukkan bahwa ROA berpengaruh positif signifikan terhadap tingkat bagi hasil deposito mudharabah atau dengan kata lain hipotesis 1 (H1) diterima. Hal ini dapat disimpulkan bahwa ketika ROA meningkat maka pendapatan Bank tersebut juga meningkat, dengan adanya peningkatan pendapatan Bank tersebut maka tingkat bagi hasil yang diterima oleh nasabah juga meningkat.

Hasil penelitian ini konsisten dengan penelitian Juwairiyah (2008) dan Anggrainy (2010), yakni ROA secara positif signifikan mempengaruhi tingkat bagi hasil deposito mudharabah. Namun, hasil penelitian ini bertentangan dengan penelitian Khasanah (2012) yang menemukan adanya pengaruh negatif dan tidak signifikan antara ROA dengan profit sharing deposito mudharabah.

ROA berpengaruh terhadap profit sharing deposito mudharabah karena apabila ROA meningkat maka pendapatan Bank juga meningkat. Dengan adanya peningkatan pendapatan Bank maka tingkat bagi hasil yang diterima oleh nasabah juga meningkat (Juwairiyah, 2008).

Semakin besar tingkat keuntungan (ROA) yang didapat oleh Bank, maka semakin besar pula upaya manajemen menginvestasikan keuntungan 
tersebut dengan berbagai kegiatan yang menguntungkan manajemen, terutama dangan penyaluran pembiayaan. Selain itu semakin besar suatu Bank menghasilkan laba maka return bagi hasil yang diberikan Bank Syariah besar berarti Bank sudah efektif dalam mengelola asetnya (Pratami, 2011).

\subsection{Pengaruh Biaya Operasional Terhadap pendapatan Operasional (BOPO) terhadap Tingkat Bagi Hasil Deposito Mudharabah}

Dalam penelitian ini, biaya operasional terhadap pendapatan operasional diukur dari perbandingan antara biaya operasional dengan pendapatan operasional. Hasil penelitian menunjukkan nilai $\beta 2$ sebesar 0,251 dengan tingkat signifikan sebesar 0,204 berada lebih besar pada $\alpha=0,05$, Hasil tersebut menunjukkan bahwa BOPO tidak berpengaruh terhadap tingkat bagi hasil deposito mudharabah atau dengan kata lain hipotesis 2 (H2) ditolak. Hal ini dapat disimpulkan bahwa biaya operasional terhadap pendapatan operasional tidak dapat dibuktikan berpengaruh terhadap tingkat bagi hasil deposito mudharabah.

Hasil penelitian ini konsisten dengan penelitian Sudiyatno dan Jati (2010), Khairiah dan Kunti (2012), dan Pramilu (2012), yang menyatakan bahwa tidak ada pengaruh antara biaya operasional terhadap pendapatan operasional dengan tingkat bagi hasil deposito mudharabah. Hal ini dikarenakan jika Bank Syariah memperoleh pendapatan operasional yang kecil maka resiko yang dimiliki Bank Syariah akan ditanggung oleh nasabah.

Akan tetapi, hasil penelitian ini tidak sesuai dengan penelitian Juwairiyah (2008) dan Anggrainy (2010) yang menyatakan bahwa biaya operasional terhadap pendapatan operasional berpengaruh positif signifikan terhadap tingkat bagi hasil deposito mudharabah. Hal ini mengindikasikan bahwa BOPO bukan faktor relevan untuk Bank Syariah dalam memberikan return bagi hasil kepada nasabahnya.

Namun hasil penelitian ini bertolak belakang dengan teori yang dikemukakan Andarini (2013) yaitu apabila BOPO menurun maka pendapatan Bank meningkat. Dengan adanya peningkatan pendapatan Bank rate of return tabungan mudharabah yang diterima oleh nasabah juga meningkat. Hal ini bukan disebabkan Bank tidak dapat mengefisienkan biayanya, namun 
disebabkan tahun-tahun pertama pasca krisis 2008, tingkat suku bunga Bank konvensional yang relatif tinggi menjadi dasar pertimbangan beberapa Bank Syariah dalam menjaga dana pihak ketiganya dengan memberikan subsidi porsi bagi hasil yang besar kepada nasabah simpanan mudharabah (Andarini, 2013).

\subsection{Pengaruh Suku Bunga terhadap Tingkat Bagi Hasil Deposito Mudharabah}

Pada uji parsial (t-test) tabel 4.4.3, penelitian ini menunjukkan bahwa nilai $\beta 3$ sebesar $-0,290$ dengan tingkat signifikan sebesar 0,090 berada lebih besar pada $\alpha=0,05$, Hasil tersebut menunjukkan bahwa Suku Bunga tidak berpengaruh terhadap tingkat bagi hasil deposito mudharabah atau dengan kata lain hipotesis 3 (H3) ditolak.

Hasil penelitian ini mendukung hasil penelitian Ipando (2008), Siddiq (2009) dan Aisiyah (2010) yang menyatakan bahwa Bank Syariah tentunya harus terbebas dari pengaruh suku bunga dan dapat menentukan sendiri nisbah bagi hasil yang mengacu pada faktor-faktor yang dapat memberikan stimulus peningkatan imbal bagi hasil. Sedangkan Bank konvensional bebas menentukan bunga yang dapat dihasilkan nasabah didepan. Walaupun secara faktor eksternal suku bunga masih menjadi baying-bayang Bank Syariah dalam mempengaruhi tingkat imbal bagi hasil. Karena jika suku bunga tinggi, maka banyak nasabah yang akan menabung ke Bank konvensional. Penyebab dasarnya adalah, nasabah melihat tingkat keuntungan yang diperoleh dibandingkan dengan menaruh dananya di Bank Syariah karena faktor rasional. Kecuali nasabah fanatik terhadap agama (spiritual) dan loyal terhadap Bank Syariah.

Akan tetapi untuk ke depan diharapkan Bank Syariah akan menjadi Bank yang berdiri sendiri tanpa dibayangi dengan tinggi rendahnya suku bunga. Sehingga Bank Syariah dapat menjadi Bank yang murni berbasis syariah dengan acuan yang lebih mengarah pada pemberdayaan umat. Namun, hasil penelitian ini tidak sesuai dengan penelitian yang dilakukan oleh Azmy (2008), dan Khairiah dan Kunti (2012) yang menemukan hasil bahwa suku bunga berpengaruh positif signifikan terhadap tingkat bagi hasil deposito mudharabah. 
Berdasarkan hasil analisis diatas, menunjukkan bahwa manajemen dari beberapa Bank Syariah yang dijadikan sampel sudah lebih baik dan telah terbukti mengurangi ketergantungan terhadap suku bunga sebagai acuan kompetitif dalam menentukan nisbah bagi hasilnya. Selain itu, juga disebabkan mulai sadarnya masyarakat terhadap keberadaan Bank Syariah yang bebas dari bunga (riba). Dimana hal ini juga terkait dengan fatwa MUI yang menyatakan bahwa bunga adalah haram, sehingga bagi masyarakat fanatik sudah tidak mempengaruhi tinggi rendahnya nisbah bagi hasil yang diperoleh. Sehingga Bank Syariah yang dijadikan sampel dalam penelitian ini tidak mengacu pada suku bunga. Sedangkan bagi nasabah rasionalis masih melihat tingkat nisbah bagi hasil yang diberikan. Hal ini tentunya menjadi tantangan bagi Bank Syariah dalam menentukan besarnya nisbah bagi hasil yang kompetitif dengan Bank konvensional agar nasabah tetap menempatkan dananya di Bank Syariah (Siddiq, 2009).

\subsection{Pengaruh Financing To Deposits Ratio (FDR) terhadap Tingkat Bagi Hasil Deposito Mudharabah}

Banyak penelitian yang meneliti mengenai hubungan pengaruh antara financing to deposits ratio terhadap tingkat bagi hasil deposito mudharabah. Berdasarkan hasil pengujian parsial variabel financing to deposits ratio terhadap tingkat bagi hasil deposito mudharabah, dapat diketahui bahwa nilai $\beta 4$ sebesar 0,226 dengan tingkat signifikan sebesar 0,027 berada lebih kecil pada $\alpha=0,05$, Hasil tersebut menunjukkan bahwa FDR berpengaruh positif signifikan terhadap tingkat bagi hasil deposito mudharabah atau dengan kata lain hipotesis 4 (H4) diterima. Hal ini dapat disimpulkan bahwa financing to deposits ratio dapat dibuktikan berpengaruh terhadap tingkat bagi hasil deposito mudharabah.

Hasil penelitian ini konsisten dengan hasil penelitian Amelia (2011) yang menunjukkan temuan bahwa terdapat hubungan antara FDR dengan tingkat bagi hasil deposito mudharabah. Penelitian Amelia (2011) yang menyatakan bahwa Financing To Deposits Ratio (FDR) berpengaruh terhadap tingkat bagi hasil deposito mudharabah. Akan tetapi, hasil penelitian ini menentang hasil penelitian Arifa (2008) yang menyatakan bahwa semakin 
banyak dana yang disalurkan dalam pembiayaan, berarti semakin tinggi earning asset, artinya dana yang dihimpun dari masyarakat dapat disalurkan kepada pembiayaan yang produktif (tidak banyak asset yang menganggur).

Alasan yang tepat untuk menjelaskan Financing to Deposits Ratio (FDR) berpengaruh terhadap tingkat bagi hasil deposito mudharabah karena semakin tinggi tingkat FDR suatu Bank, maka Bank tersebut akan berusaha untuk meningkatkan perolehan dananya, salah satunya dari sisi deposito, untuk menarik investor menginvestasikan dananya di Bank Syariah, maka diberikanlah tingkat bagi hasil yang menarik, sehingga peningkatan FDR akan meningkatkan return bagi hasil deposito mudharabah (Amelia, 2011).

\subsection{Pengaruh Non Performing Financing (NPF) terhadap tingkat bagi hasil deposito mudharabah (H5)}

Non Performing Financing (NPF) sebagai variabel dalam penelitian ini tidak dapat dibuktikan berpengaruh terhadap tingkat bagi hasil deposito mudharabah pada tingkat signifikansi sebesar 0,074 (0,074 $>0,05)$, Hasil tersebut menunjukkan bahwa NPF tidak berpengaruh terhadap tingkat bagi hasil deposito mudharabah atau dengan kata lain hipotesis 5 (H5) ditolak. Hasil penelitian ini mendukung penelitian yang dilakukan oleh Pratin dan adnan (2005) Mutamimah dan Siti (2012). Hal ini dikarenakan permintaan pembiayaan yang cukup tinggi di Bank Syariah, kekhususan dalam penanganan pembiayaan bermasalah dibanding dengan Bank konvensional, dan kecilnya peluang moral hazard pada Bank Syariah. Namun, hasil penelitian ini tidak mendukung hasil penelitian yang dilakukan oleh Amelia (2011) yang menyatakan NPF berpengaruh positif signifikan terhadap tingkat bagi hasil. Hal ini mengindikasikan bahwa NPF bukan faktor relevan untuk Bank Syariah dalam memberikan return bagi hasil kepada nasabahnya.

Hasil penelitian ini tidak sesuai dengan teori yang dikemukakan Amelia (2011) yang menyatakan jika kualitas asset yang dicerminkan oleh NPF semakin meningkat, maka efektif pendapatan Bank Umum Syariah dari earning asset akan semakin berkurang dan akibatnya akan menurunkan return bagi hasil yang dibagikan kepada nasabah. 
Beberapa alasan NPF tidak mempengaruhi tingkat bagi hasil yang diberikan oleh Bank Syariah adalah sebagai berikut:

- Permintaan pembiayaan di Bank Syariah cukup tinggi

- Penanganan Pembiayaan Bermasalah Pada Bank Syariah.

- Kecilnya Moral Hazard Pada Bank Syariah

\section{KESIMPULAN}

Berdasarkan hasil penelitian serta pembahasan bab sebelumnya mengenai analisis pengaruh ROA, BOPO, SUKU BUNGA, FDR dan NPF terhadap tingkat bagi hasil deposito mudharabah mempunyai beberapa kesimpulan, yaitu:

1. Return On Asset (ROA) berpengaruh positif signifikan terhadap tingkat bagi hasil. Hal ini dibuktikan dengan besarnya koefisien regresi sebesar 0,127 dan tingkat signifikansinya sebesar 0,000 lebih kecil dari nilai signifikansi yaitu 5\%. Semakin tinggi nilai ROA yang diperoleh Bank, maka semakin besar pula pendapatan Bank dan semakin besar pula tingkat bagi hasil yang diberikan oleh Bank Syariah kepada nasabah. Oleh karena itu hipotesis 1 (H1) diterima.

2. Biaya Operasional Terhadap Pendapatan Operasional (BOPO) tidak berpengaruh terhadap tingkat bagi hasil. Hal ini dibuktikan dengan besarnya koefisien regresi sebesar 0,251 dan tingkat signifikansinya sebesar 0,204 lebih besar dari nilai signifikansi yaitu 5\%. Hasil ini tidak sesuai dengan teori yang menyatakan bahwa apabila BOPO menurun maka pendapatan Bank meningkat. Dengan adanya peningkatan pendapatan Bank rate of return tabungan mudharabah yang diterima oleh nasabah juga meningkat. Oleh karena itu hipotesis 2 (H2) yang menyatakan BOPO berpengaruh positif terhadap tingkat bagi hasil ditolak.

3. Suku Bunga tidak berpengaruh terhadap tingkat bagi hasil. Hal ini dibuktikan dengan besarnya koefisien regresi sebesar -0,290 dan tingkat signifikansinya sebesar 0,090 lebih besar dari nilai signifikansi yaitu 5\%. Hasil ini tidak sesuai dengan teori yang menyatakan jika tingkat suku bunga pada Bank konvensional naik, maka tingkat bagi hasil yang diberikan Bank juga akan meningkat. Oleh karena itu hipotesis 3 (H3) yang menyatakan bahwa Suku Bunga berpengaruh positif terhadap tingkat bagi hasil ditolak. 
4. Financing To Deposits Ratio (FDR) berpengaruh positif signifikan terhadap tingkat bagi hasil. Hal ini dibuktikan dengan besarnya koefisien regresi sebesar 0,226 dan tingkat signifikansinya sebesar 0,027 lebih kecil dari nilai signifikansi yaitu 5\%. Hasil ini mengindikasikan bahwa ketika nilai FDR tinggi menunjukkan semakin baiknya fungsi intermediasi Bank yang bersangkutan dan mengindikasikan tingkat pembiayaan yang tinggi dan berdampak pada meningkatnya return yang akan dihasilkan dari pembiayaan yang secara otomatis meningkatkan tingkat bagi hasil. Oleh karena itu hipotesis $4(\mathrm{H} 4)$ diterima.

5. Non Performing Financing (NPF) berpengaruh tidak berpengaruh terhadap tingkat bagi hasil. Hal ini dibuktikan dengan besarnya koefisien regresi sebesar 0,030 dan tingkat signifikansinya sebesar 0,074 lebih besar dari nilai signifikansi yaitu 5\%. Hal ini mengindikasikan bahwa NPF bukan faktor utama yang mempengaruhi tingkat bagi hasil yang diberikan oleh Bank Syariah. Hasil ini tidak sesuai dengan teori yang menyatakan bahwa jika kualitas asset yang dicerminkan oleh NPF semakin meningkat, maka efektif pendapatan Bank Umum Syariah dari earning asset akan semakin berkurang dan akibatnya akan menurunkan return bagi hasil yang dibagikan kepada nasabah. Oleh karena itu hipotesis 5 (H5) yang menyatakan bahwa NPF berpengaruh negatif terhadap tingkat bagi hasil ditolak.

\section{Saran}

Berdasarkan hasil penelitian yang mengacu pada perumusan penelitian, tujuan dari penelitian dan keterbatasan penelitian ini serta pembahasan bab sebelumnya mengenai analisis pengaruh ROA, BOPO, SUKU BUNGA, FDR dan NPF terhadap tingkat bagi hasil deposito mudharabah, maka penulis memberikan saran sebagai berikut:

1. Meneliti pengaruh pembiayaan bagi hasil tidak hanya faktor internal Banknya saja, peneliti berikut hendaknya menambah faktor eksternal Bank Syariah dalam meneliti apa yang mempengaruhi tingkat bagi hasil dalam produk perbankan syariah yaitu deposito mudharabah. 
2. Penelitian selanjutnya diharapkan memperpanjang jangka waktu penelitian agar hasilnya lebih akurat.

3. Menambah variabel lain yang dapat mempengaruhi tingkat bagi hasil seperti ROE, DPK dan inflasi agar hasilnya lebih memperkuat pengaruh tingkat bagi hasil yang diberikan oleh Bank umum syariah di Indonesia.

4. Menambah variabel atau sampel yang digunakan agar model regresi yang digunakan lebih bagus dan lebih tinggi nilai autokorelasinya.

\section{REFERENSI}

Aisiyah, Sinta. 2010. Faktor-faktor yang mempengaruhi bagi hasil pada bank syariah mandiri (periode juni 2005-mei 2009). Skripsi UIN Sunan Kalijaga.Yogyakarta.

Amelia, Rizky. 2011. Pengaruh CAR, FDR dan NPF Terhadap Return Bagi Hasil Deposito Mudharabah Pada perbankan Syariah. Skripsi UIN Syarif Hidayatullah. Jakarta.

Andarini, Indarti Purwa. 2013. Pengaruh Persistensi Kinerja Keuangan dan Efisiensi Terhadap Rate Of Return Tabungan Mudharabah. Skripsi UIN Sunan Kalijaga. Yogyakarta.

Andryani Isna K dan Kunti Sunaryo. 2012. “ Analisis Pengaruh Return On Asset (ROA), BOPO, Terhadap Tingkat bagi Hasil Deposito Mudharabah Pada Bank Umum Syariah, Jurnal Ekonomi dan Bisnis, Volume 11, No 01.

Anggrainy, Dian. 2010. Pengaruh Kinerja Keuangan Terhadap Tingkat Bagi Hasil Deposito Mudharabah Pada Bank Umum Syariah. Skripsi UIN Sunan Kalijaga.Yogyakarta.

Anisah, Nur, Akhmad Riduwan, Lailatul Amanah. 2013. Faktor-faktor yang mempengaruhi pertumbuhan deposito mudharabah bank syariah. Jurnal ilmu dan riset akuntansi.vol 1 nomor 2 maret.

Apriandika, Rangga. 2011. Analisis hubungan kinerja keuangan terhadap tingkat bagi hasil simpanan mudharabah pada bank syariah. Jurnal. Universitas Lampung.

Arifa, Umaira. 2008. Analisis Pengaruh Non Performing Financing (NPF) dan Financing To Deposit Ratio (FDR) terhadap persentase return bagi hasil deposito mudharabah mutlaqah pada Bank Muamalat Indonesia. Dalam skripsi UIN Syarif Hidayatullah. Jakarta 
Azmy, M. Showwam. 2008. Analisis Faktor-faktor yang Mempengaruhi Tingkat Bagi Hasil Simpanan Mudharabah Pada Bank Umum Syariah di Indonesia Tahun 2005-2008.UIN Sunan Kalijaga.Yogyakarta.

Dewan Syariah Nasional Majelis Ulama Indonesia, Fatwa Dewan Syariah Nasional No: 3/DSNMUI/IV/2000 tentang Deposito

Fatwa MUI No. 1 tahun 2004 Tentang Bunga.http://www.mui.or.id. Diunduh pada 15 Desember 2013

Ghozali, Imam. 2011. Aplikasi Analisis Multivariate dengan Program IBM SPSS 19. Cetakan V. Semarang : Badan Penerbit Universitas Diponegoro.

Ipando, Ogi Marsenal. 2008. "Pengaruh bagi Hasil Deposito Syariah Mandiri dan Suku Bunga Deposito Bank Umum Terhadap Jumlah Simpanan Deposito Syariah Mandiri di Bank Syariah Mandiri". Skripsi UIN Sunan Kalijaga. Yogyakarta

Juwariyah, Siti. 2008. Analisis Pengaruh Profitabilitas dan Efisiensi terhadap tingkat bagi hasil tabungan dan Deposito Mudharabah Muthlaqah Studi Bank Muamalat Indonesia. Skripsi UIN Sunan Kalijaga.Yogyakarta.

Khasanah, Ulfah. 2012."Analisis pengaruh pendapatan bank, DPK, dan ROA terhadap profit sharing deposito mudharabah pada PT Bank Syariah Mandiri tahun 20082011. Skripsi IAIN Walisongo

Mawardi, Nasrah. 2008. Faktor-faktor yang Mempengaruhi Penetapan Return Bagi Hasil Deposito Mudharabah Muthlaqah: studi pada Unit syari'ah Bank X. Jurnal Eksis,Vol. 4. No 1.

Merkusiwati, Ni Ketut Lely Aryani. 2007. “Evaluasi Pengaruh Camel Terhadap Kinerja Perusahaan", Buletin Studi Ekonomi, Vol. 12, No. 1

Muhammad. 2005. Bank Syariah Problem Dan Prospek Perkembangan Di Indonesia, Cetakan Pertama. Yogyakarta: Graha Ilmu.

Muhammad. 2005. Manajemen Bank Syariah. Yogyakarta: UPP AMP YKPN.

Mutamimah dan Siti. 2012. "Analisis Eksternal dan Internal dalam Menentukan Non Performing Financing Bank Umum Syariah di Indonesia". Jurnal Bisnis dan Ekonomi. Vol 19 No 1. ISSN 1412-3126.

Nainggolan, Marnov. 2009. Analisis LDR, NIM, BOPO Terhadap ROA Bank Umum Indonesia. Skripsi Universitas Sumatera Utara. Medan 
Nelwani, Cesaria Yomi Edy. 2013. Faktor-faktor yang mempengaruhi deposito mudharabah pada Bank Umum Syariah (BUS) periode 2009-2012. Skripsi UIN Sunan Kalijaga. Yogyakarta.

Nurkhosidah, Siti. 2009. Analisis Pengaruh Variabel Non Performing Financing, Penyisishan Penghapusan Aktiva Produktif, Financing To Deposit Ratio, Biaya Operasioanal Per Pendapatan Operasional terhadap profitabilitas pada Bank Syariah Mandiri. Skripsi UIN Sunan Kalijaga. Yogyakarta

Outlook Perbankan syariah tahun 2012 Diakses tanggal 18 Mei 2013 di www.bi.go.id Pramilu, Hadi Asy'ari. 2012. Pengaruh Kinerja Keuangan Terhadap Tingkat Bagi Hasil Deposito Mudharabah Pada Bank Umum Syariah. Skripsi UIN Sunan Kalijaga.Yogyakarta.

Pratami, Wuri Arianti Novi. 2011. “Analisis Pengaruh Dana Pihak Ketiga (DPK), Capital Adequacy Ratio (CAR), Non Performing Financing (NPF) dan Return On Asset (ROA) terhadap pembiayaan pada perbankan syariah". Skripsi. Universitas Diponegoro. Semarang

Pratin dan Akhyar Adnan. 2005. "Analisis Hubungan Simpanan, Modal Sendiri, NPL, Prosentase Bagi Hasil dan Mark Up Keuntungan Terhadap Pembiayaan Pada Perbankan syariah Studi Kasus Pada Bank Muamalat Indonesia (BMI)”. Jurnal SINERGI Kajian Bisnis dan Manajemen ISSN 1410-9018.

Purwanto, Tri Joko. 2011. Analisis besarnya pengaruh Pembiayaan, Financing To Deposits Ratio (FDR), dan Rasio Non Performing Financing (NPF) terhadap laba bank syariah (studi kasus PT. Bank Muamalat Indonesia.Tbk). Skripsi Institut Pertanian Bogor. Bogor

Rizqiana, Rizqa. 2010. “Pengaruh Bagi Hasil terhadap Jumlah dana Deposito Syariah Mudharabah Yang Ada pada Bank Syariah Mandiri. Skripsi UIN Syarif Hidayatullah. Jakarta

Siddiq, Abu Bakar. 2009. "Pengaruh Jumlah Pendapatan, Penyaluran Tabungan, Nisabah dan BI Rate Terhadap Tingkat Imbal Bagi Hasil Nasabah dengan Skim Mudharabah. Skripsi UIN Syarif Hidayatullah. Jakarta.

Sri, Anastasya, Ratna Anggraini, Etty Gurendrawati, Nurmalia Hasanah. 2013. The Influence of Third-Party Funds, Car, Npf and Roa Against The Financing of A 
General Sharia-Based Bank in Indonesia. International Conference on Business, Economics, and Accounting, 20-23 maret di Bangkok, Thailand.

Sugiyono. 2010. Metode Penelitian Bisnis. Cetakan Ke-15. Bandung : Alfabeta

Statistik Perbankan Syariah 2009 Diakses tanggal 18 Mei 2013 di www.bi.go.id

Statistik Perbankan Syariah 2010 Diakses tanggal 18 Mei 2013 di www.bi.go.id

Statistik Perbankan Syariah 2011 Diakses tanggal 18 Mei 2013 di www.bi.go.id

Statistik Perbankan Syariah 2012 Diakses tanggal 18 Mei 2013 di www.bi.go.id

Statistik Perbankan Syariah 2013 Diakses tanggal 18 Mei 2013 di www.bi.go.id

Tarsidin. 2010. Bagi Hasil : Konsep dan Analisis. Lembaga Penerbit Fakultas Ekonomi Universitas Indonesia. Jakarta.

Undang-Undang Republik Indonesia No. 7 Tahun 1992

Undang-Undang Republik Indonesia No. 10 Tahun 1998 Tanggal 10 November 1998 tentang perbankan

Undang - Undang Republik Indonesia No. 21 tahun 2008 tentang Perbankan syariah www.bi.go.id 